\title{
Procedures for Completing Small Claims Lawsuit of Civil Cases in District Court in Indonesia
}

\author{
Marjo \\ Nanik Rofikoh \\ Diponegoro University, \\ Semarang, Indonesia
}

Doi: 10.36941/ajis-2020-0o48

\begin{abstract}
The development of legal relations in the economic and other civil sectors in community highly requires a faster and less costly dispute resolution process, especially in small civil disputes. In connection with this matter, Indonesian Supreme Court issued various Supreme Court regulations, including Regulation No. 2 of 2015 concerning Procedures for Completion of Small Claims. The issuance of this regulation was to resolve special civil disputes regarding the acts against the law. In a small claim court lawsuit, it is required that the plaintiff and defendant be in the same jurisdiction. The value of the material suit in a small claim lawsuit is at most IDR 200 million or equal to 13,811 USD. Furthermore, for a small claim examination and verification of a lawsuit, it is carried out in a small manner, where the period of completion is determined a maximum of 25 days from the first trial day to the decision.
\end{abstract}

Keywords: district court, civil case, small lawsuit, Supreme Court regulation, Indonesia

\section{Introduction}

The development of legal relations in the economic and other civil sectors in the community requires procedures for dispute resolution that are faster and less costly, especially in small legal relationships (Roisah et al., 2018). Judicial reforms to accelerate the process and reduce legal costs have long been applied in various countries in various legal contexts (McMillan Jr \& Siegel, 1984; Thornburg, 2002; Budd \& Colvin, 2008; Cortes, 2008) The Supreme Court made several breakthroughs in realizing the principle of justice in Indonesia, one of which is the issuance of Supreme Court Regulation (in Indonesian: Perma) No. 2 of 2015 concerning Procedures for Completing Small Claim Court Lawsuit (referred to as small claims) which is then abbreviated as Perma No. 2 of 2015, stipulated by Chief Justice of the Supreme Court, Muhammad Hatta Ali in Jakarta on August 7, 2015. Article 1 paragraph (1) Perma No. 2 of 2015 states that a small claim is a procedure for examining in a court case against a civil lawsuit against an unlawful act with a maximum material claim of $\mathrm{Rp} 200$ million which is settled by small procedure and verification (Rohman \& Sugeng, 2018). In addition, this small claim is examined and decided by a single judge within the scope of public court authority (Afriana, 2017). In a small claim, the mechanism and procedure for settling civil cases are carried out simply, and only on cases based on injury and/or legal actions and with the determination of the material claim value of 200 million IDR or equal to 13,811 USD, that must be completed no more than 25 days from the first 
trial day to the decision.

Another consideration was issued by Perma No. 2 of 2015 that the administration of justice is carried out with a small, fast, and low cost principle to open wide access for the public to obtain justice. That settlement of civil cases was historically regulated in Herziene Indonesisch Reglement (H.I.R.) (S.1848-16) and Rechtsreglement Buitengewesten (RBg) as civil procedural law applicable in Dutch East Indies, the now Indonesia (see. Antons, 2017; Seyto Handono et al., 2018; Pompe, 1982; de Moor \& Rothermund, 1994; Deguchi \& Storme, 2008). The regulation from Supreme Court is carried out by examination without further differentiating the value of objects and claims and small proof so that for the completion of small cases it takes a long time. The 2015-2019 National Medium-Term Development Plan mandates the easy and fast reform of the civil law system to regulate issues related to the economy through small claim court disputes, other considerations from the issuance of this Perma namely that the Supreme Court can further regulate matters needed for the smooth operation of the judiciary if there are matters that are not sufficiently regulated in the law to fill the gap or legal vacuum. Some formulations of the problems that will be discussed are the mechanism procedure to apply the Perma No. 2 of 2015, the obstacles in the application, and to strategic to overcome the obstacles that arise in the application of the Perma No. 2 of 2015.

\section{Research Method}

This research is intended to provide a systematic, comprehensive description of the application of Perma No. 2 of 2015 conducted by outlining various findings both from primary and secondary data. The specification of analytical descriptive research will be disclosed legislation relating to legal theories that are the object of research (Ali, 2013). Data obtained from the results of the research are related to legislation, legal theories and practices in the field related to the subject matter. The subjects in this study are those who are directly related to the application of Perma No. 2 of 2015, the subject in question which includes those who examine and decide on civil cases based on Perma No. 2 of 2015, namely judges and those who administer civil cases based on Perma No. 2 of 2015 in the district court, namely the registrar.

\section{Fundamental Procedure for Settling Civil Cases in District Courts}

Article 3 of Law No. 2 of 1986 concerning General Courts stated that judicial power in the general court is carried out by the district court and the high court, culminating in the Supreme Court. The district court is domiciled in the regency/city capital, with the legal area covering the regency/city area. Moreover, Article 10 of Law No. 48 of 2009 concerning Judicial Power stated that the court has the obligation to examine, hear, and decide on a case filed with him. The procedure for settling civil cases in district courts in Indonesia is fundamental to HIR and RBg. HIR (Herziene Indonesische Reglement) was adopted based on the concordance principle because it was a product of the Dutch colonial government which is still valid today, with reference to Article 2 of the Transitional Rules of the 1945 Constitution (Termorshuizen-Arts, 1994; Hornick, 1977). The HIR was translated as an updated Indonesian regulation (Agustine, 2017). HIR is applied to Java and Madura regions. RBg (Reglement voor de Buitengewesten) is translated as cross-regional legal regulations (Hamzah, 2016). This is an procedural law that applies to areas outside Java and Madura. This regulation only contains things that are still considered necessary for the present situation with adjustments as needed. The procedures for resolving a small claims in a district court include registration, small claims check, determination of judges and appointment of replacement clerks, preliminary examination, determination of trial day and summons of parties, examination of the trial and peace, proof, decision, and legal fee. 


\section{Obstacles in the Application of Supreme Court Regulation}

The obstacles in the application of Perma No. 2 of 2015 can be divided into two factors that are internal and external barriers. Internal barriers refer to obstacles originating from the court which are directly experienced in the application of Perma No. 2 of 2015. The completion of a small claims in court from the registration stage has been stipulated in the articles at Perma No. 2 of 2015, while the process of submitting and examining small claims still uses procedural principles. The sequence of the stages of completing a small claims in a court that starts from the registration until the verdict is the same as the sequence of stages of the ordinary lawsuit settlement. In the district court the number of cases handled by judges is relatively large, so that a small procedural settlement process will allow conflict to occur with the period of examination stipulated in Perma No. 2 of 2015. Just as in the process of proof, in a small claim the proof is still the same as the usual proof system, so it can also influence the length of the examination process to the verdict. Another obstacle experienced is in determining the value of the claim, where the claim of the plaintiff in the form of material demands can coincide with immaterial demands. In its development, fundamental demands on defaults or acts against the law, besides being able to propose material demands, can also submit immaterial demands. One example that mentions immaterial demands on unlawful acts, namely in Article 1372 of the Civil Code, civil claims regarding matters of insult are submitted to obtain compensation and the restoration of honor and good name. Judging from the article, it is possible for a person to submit a material claim and immaterial demand. Perma No. 2 of 2015 only mentions the value of material claims, against immaterial claims there is no regulation. Article 4 Paragraph (4) Perma No. 2 of 2015 stated that the parties must attend directly every trial with or without an attorney, based on the article above, it will allow one or both parties to be accompanied by a lawyer/advocate because there is no prohibition. When one of the parties or both uses the services of an advocate in the peace process that will be sought by the judge, the parties will ask for a recommendation from the lawyer so that it is no longer purely based on the thoughts of the parties. This will result in more difficulty in achieving peace. Article 15 Paragraph (2) Perma No. 2 of 2015 stated that peace efforts in the settlement of small claims exclude Supreme Court provisions regarding mediation procedures. Peace efforts by the judge are carried out in the first day's trial while paying attention to the time limit specified in the small claims, this can result in peace being sought in a small claims that is not optimal.

External barriers are obstacles that come from outside the court, including the existence of the parties in dispute that are not always in the same jurisdiction, this narrows the range of small claims so that not all civil disputes whose material claim value is under 200 million can be netted. The defendant's unknown place of residence or domicile can also narrow the range of small claims, when someone who is in a dispute that is included in the civil domain with a material claim value of less than 200 million cannot be presented as a small claim because it is obstructed by domicile or the defendant's unknown residence. Another obstacle that arises is the presence of the parties at a predetermined hearing that is not fulfilled. It can be said that the defendant for a small claims is not accommodative. The Defendant ignored the call to attend the trial on the day of the trial that had been set by the court so that it would hinder the process of examination and the small claim did not get the settlement as expected. The domicile of parties is also one of the obstacles when litigants are domiciled relatively far from the courts, especially those in the regency area for areas where the law is fundamental to the RBg. This will allow parties not to attend the trial under the pretext of distance and costs to the court that cannot be reached by the parties, so that it will hamper the inspection process which can result in the delay of the small settlement of the claim. The lack of legal awareness of the community and the lack of socialization of the existence of a small claim is also one of the obstacles, so that it will be possible for people who do not know about this small claim. 


\section{Strategies to Clarify the Completion of Small claims}

Based on internal and external barriers in the Implementation of Perma No. 2 of 2015, it is hoped that an effort will be overcome. The efforts that will be recommended by the author are that for the process of submission and examination of small claims that still use procedural principles so that it will allow the occurrence of conflicts with the period of examination stipulated in Perma No. 2 of 2015, which is 25 days, then the process of submitting a small claim other than being proposed simply directly can also be done by registering, submitting responses and preliminary examinations electronically. Regarding the basic electronic case administration process in the Perma No. 3 of 2018 concerning electronic case administration in the district court. The Perma is a series of processes for receiving claims/requests, answers, replicating, duplicating and concluding, managing, submitting and storing civil/religious/military/ administrative case documents using the applicable electronic system in each of the judicial environments, with a view to supporting the realization of an orderly, transparent, accountable, effective, efficient and modern case administration (Machmudin, 2018). Registration, submission of responses, preliminary examinations and calls to parties to attend hearings on a small claims can be carried out electronically fundamentally at Perma No. 3 of 2018 to make the payment of fees for small claim cases cheaper and the process faster.

The electronic administration process can also be an attempt to overcome the obstacles to not encroaching all civil disputes whose material value is below 200 million IDR due to the existence of parties not in one jurisdiction, so that a small claims settlement system in litigation does not need to be distinguished and the range of small claims will be even wider. The domicile of the parties that are relatively far away to those in the district so that it becomes an obstacle to attend the trial, can also be overcome by an electronic settlement system, so that the parties do not have to be present directly to the court and the obstacles to the presence of the parties do not become more obstacles (for comparison, see. Ramiyanto, 2017). For the defendant who has not detected his residence/domicile, the claim can be submitted to the plaintiff's domicile.

The presence of parties at a preset hearing that is not fulfilled can also be due to the attitude of the parties to a small claims that is not accommodative, where the defendant ignores the call to attend the trial on the determined trial day and this will be a barrier. Efforts that can be made in overcoming that are with the active role of the court in the calling process so that the parties present, if the notification process of the summons cannot meet directly with the parties being able to be done by telephone call. The obstacle in the peace process sought by a judge who is not optimal on a small claim examination is because it is not like an ordinary claim examination, the peace process can be carried out as in the case of an ordinary lawsuit with the Supreme Court's provisions regarding mediation, namely Perma No. 1 of 2016. This is achieved because the parties are accompanied by advocates so that they are no longer purely thought by the parties, but there will be recommendations from advocates that they can be overcome by assistance by advocates in certain matters and excluded from the peace process .

In the process of proofing in a small claims that is still the same as the system of verification on ordinary lawsuits or it can be said that there is no difference, it can be solved by proof of a small claims, which in the process of proving all evidence both the plaintiff and the defendant is made in one examination and checked at one stage of the trial, can also be added to the time limit for the process of proof. Regarding the determination of the claim against the plaintiff's demands in the form of material demands can coincide with immaterial demands, it should not be necessary to distinguish between the plaintiff's demands, as long as the plaintiff's lawsuit, both material and immaterial, can be submitted as a small claim. Perma No. 2 of 2015 requires more socialization efforts to the general public, can be done by procuring special funds for socialization efforts by the court so that it is expected that the existence of Perma No. 2 of 2015 is widely known and can increase legal awareness for the community. 


\section{Conclusion}

The Supreme Court issued Perma No. 2 of 2015 as an effort to realize the principle of justice in Indonesia, namely small, fast, and low cost and also see that the development of legal relations in the economy and other civil societies requires a smallr, faster and more costly dispute resolution process especially for small civil disputes. A small claims is a procedure for examining a court case against an injury and/or an illegal act in which the plaintiff and defendant are in the same legal jurisdiction, with the determination of the material claim value of a maximum of 200 million IDR, which is settled by a small procedure of proof. The judge who checks and decides on a small claims is a single judge and for a small period of settlement of the claim since the first trial day has been determined which is 25 days. Against the application of Perma No. 2 of 2015 in principle has no difference, thus it can be interpreted that the application of Perma No. 2 of 2015 in the district court the entire national territory is the same, from the registration stage until the fundamental decision at Perma No. 2 of 2015. The obstacles that arise both internally and externally on the application of Perma No. 2 of 2015 with the HIR and the RBg do not have many differences, so that efforts to overcome barriers arising in the district court with fundamental law to the HIR and the district courts whose fundamental laws on RBg are the same.

\section{References}

Afriana, A. (2017). Questioning the Small-claims Court in Indonesia in the Framework of National Civil Procedural Law Reform. Jurnal Dinamika Hukum, 16(3), 266-272.

Agustine, D. (2017). Pembaharuan Sistem Hukum Acara Perdata. Jurnal Rechtsvinding (2016), 1-7.

Ali, Z. (2013). Metode Penelitian Hukum. Jakarta: Sinar Grafika.

Antons, C. (2017). Law and Society in East Asia. Routledge.

Budd, J. W., \& Colvin, A. J. (2008). Improved metrics for workplace dispute resolution procedures: Efficiency, equity, and voice. Industrial Relations: A Journal of Economy and Society, 47(3), 46o-479.

Cortes, P. (2008). Does the proposed European Procedure enhance the resolution of small claims?. Civil Justice Quarterly, 27(1), 83-97.

de Moor, J., \& Rothermund, D. (1994). Our laws, their lands: Land laws and land use in modern colonial societies (No. 2). LIT Verlag Münster.

Deguchi, M., \& Storme, M. (Eds.). (2008). The reception and transmission of civil procedural law in the global society: legislative and legal educational assistance to other countries in procedural law. Garant.

Hamzah, M. A. (2016). Reform of Civil Procedural Law at the Appellate-level Courts in Indonesia. Mimbar Hukum 28(2), 348-364.

Hornick, R. N. (1977). Recognition and Enforcement of Foreign Judgments in Indonesia, The. Harv. Int'l. LJ, 18, 97.

Machmudin, D. D. (2018). Modernization and acceleration of case standard handling and reviewing on Indonesia supreme court. Journal of Legal, Ethical and Regulatory Issues, 21(3), 1-7.

McMillan Jr, R., \& Siegel, D. B. (1984). Creating a Fast-Track Alternative Under the Federal Rules of Civil Procedure. Notre Dame L. Rev., 6o, 431.

Pompe, S. (Ed.). (1992). Indonesian law 1949-1989: a bibliography of foreign-language materials with brief commentaries on the law. Martinus Nijhoff Publishers.

Ramiyanto, R. (2017). Bukti elektronik sebagai alat bukti yang sah dalam hukum acara pidana. Jurnal Hukum dan Peradilan, 6(3), 463-484.

Rohman, A. N., \& Sugeng, S. (2018). Probabilitas mekanisme small claim court dalam penyelesaian sengketa waris di pengadilan agama/probability of small claim court mechanism in resolving inheritance disputes in religious court. Jurnal Hukum dan Peradilan, 7(3), 387-404.

Roisah, K., Utama, Y.J., Saraswati, R., \& Whidari, Y.(2018). Status and contemporary development of employee inventions ownership in G-20 countries. European Research Studies Journal, 21(2), 214-224

Seyto Handono, D., Poesoko, H., Rekso Wibowo, B., \& Harianto, A. (2018). The Simple, Fast and Low Cost Principles of the Civil Verdict Related to the Exception of Obscuur Libels on Land Disputes. JL Pol'y \& Globalization, 8o, 56 .

Termorshuizen-Arts, M. (1994). Revise en Herziening: De Continuïteit in de Indonesische Rechtspleging. Bijdragen tot de Taal-, Land-en Volkenkunde, (2de Afl), 330-356.

Thornburg, E. G. (2002). Fast, cheap, and out of control: Lessons from the ICANN dispute resolution process. J. Small \& Emerging Bus. L., 6, 191. 